\title{
A JOURNEY OF DISCOVERY THROUGH THE LIVONIAN WORLD: THE SCHOLARLY WORK OF TIIT-REIN VIITSO
}

\author{
Tuuli Tuisk and Karl Pajusalu \\ University of Tartu
}

\begin{abstract}
This article presents a survey of Tiit-Rein Viitso's studies on Livonian. Viitso has studied a variety of aspects of this southernmost Finnic language. In the current article, Viitso's studies on Livonian are grouped into six parts: studies on (1) Livonian pronunciation and word prosody; (2) grammar; (3) vocabulary; overviews of the (4) Livonian language; the (5) Livonian language in the Finnic context; and (6) Livonian folklore, culture, and people. The most important part of Viitso's Livonian studies concerns gradation in Livonian and its complicated system of morphophonological alternations. His research activities have been crowned with remarkable monumental works including the largest Livonian dictionary to date with an extensive grammatical survey (2012). Being deeply interested in the Finnic languages, Viitso has studied the historical contacts of the Livonian language and its broader Finnic context.
\end{abstract}

Keywords: Tiit-Rein Viitso, Finnic languages, Livonian, research history

DOI: https://doi.org/10.12697/jeful.2018.9.2.01

\section{Introduction}

Professor Emeritus Tiit-Rein Viitso's scholarly career has been highly multifaceted. As an inquisitive person, his interest has been drawn to numerous languages and language families. In addition to the Uralic and Indo-European languages, he has also had involvement with Native American languages, i.e., Penutian and Athabaskan languages. As a contributor to various encyclopaedias, he has prepared surveys of the world's languages and language groups.

Viitso's primary and also favourite field of research has been the Finnic languages - their history, structure, vocabulary, and phonological systems - and he has been involved in the classification of these languages and their dialects. His first articles focussed on Votic and Veps. In his first scientific article (1961) he described Votic phonology, 
namely the Luutsa-Liivtšülä sub-dialect. His candidate dissertation (1966) was a glossematic analysis of northern Veps.

Viitso's scientific work with Livonian started in the beginning of the 1970s. In the summer of 1972, he did his first fieldwork in Courland. And from that point on, he returned to do more fieldwork nearly every year, so that he could collect new materials and study Courland Livonian. As a result of his decades of fieldwork and research, a large number of articles on Livonian and its linguistic context have been published.

However, Viitso's very first contact with Livonian came already when he was still an eight or nine year old schoolboy. He read a book about Estonian history (published in 1919) which contained the sentence "Esimeste ristitud liiwlaste hulgas olid Ülo, Wiitso, Kaupo ja Anno." ("Ülo, Wiitso, Kaupo, and Anno were among the first baptised Livonians.", see Figure 1) ${ }^{1}$. His name - Viitso - was connected to the Livonians, which makes it seem almost like destiny that he would come to have this interest in the Livonians and their language, and that it would continue for his entire life.

tama ja ristima. Missionitöö kaswis esmalt jõudsasti, sest et tähtsamad liiwlaste wanemad ristiusu wastu wõtsid. Esimeste ristitud liiwlaste hulgas olid Ülo, Wiitso, Kaupo ja Anno. Kui talwel 1186 Leedu rahwas maad riisuma tuli ja hulga liiwlasi wangi wiis, wõttis Meinhard seltsimeestega sõjariistad kätte, seadis ennast metsa üles, kust waenlased pidid läbi minema, langes ilma ootamata nende kallale ja wõttis saagi

Figure 1. A fragment from "Eesti ajalugu" (Estonian history, 1919).

Tiit-Rein Viitso has an important role in the work relating to the Livonian language, culture and people. In 2008, when the International Society of Livonian Friends was founded, he was elected to be its chairman. He continues to hold this title today. During the last decades, he has been a great supporter of various Livonian endeavours and is warmly welcomed as a friend of the Livonians at many events. His knowledge, insight, and suggestions concerning various Livonian topics have been and continue to be extremely valuable.

1 See an interview with Tiit-Rein Viitso in LA 2018 (Līvlizt āigastrōntõz 2018). 
In addition to his scholarly research on Livonian, Viitso has edited books and articles on Livonian-related topics and taught this language to Livonian descendants. For many years, he has taught Livonian-language courses at the University of Tartu. A number of his students have gone on to be successful researchers thanks to his training, and several of them have even defended their BA, MA, and PhD theses on topics relating to Livonian.

It is no longer possible to revive the dialect diversity that Livonian once had. The need for common rules and a unified orthography has been discussed for several decades. The most significant issue in the development of the written language has been the choice of the dialect on which to base it. Viitso has been actively involved in these subjects and the development of standard Livonian.

\section{Research on Livonian}

Tiit-Rein Viitso has been engaged in productive academic and public work on Livonian for decades. Without a doubt, at this time he is the world's premiere living expert on Livonian. Livonian is the language Viitso has studied from the largest variety of perspectives. His interest was first drawn to Livonian pronunciation and its complicated word prosody. The fact that Livonian went on to become a lifelong focus of Viitso's research can also be seen in the name of his monumental book "Liivi keel ja läänemeresoome keelemaastikud" (The Livonian language and Finnic linguistic landscapes, 2008a). This book is an expanded collection of Viitso's most important studies on Livonian as well as other Finnic languages, and also includes a selected bibliography of his scholarly work from 1961 until 2007.

Some may argue with the method for grouping Viitso's studies in the following sections; however, we hope our approach discussion helps to provide a better picture of his extensive research into one of his favourite languages.

\subsection{Studies on Livonian pronunciation and word prosody}

Tiit-Rein Viitso is first and foremost a phonologist and has studied questions relating to Livonian phonology in its various aspects (e.g., 1974, 1975, 1981a, 2008a). He was the first to have identified the main tone and quantity patterns in Livonian and explained its prosodic alter- 
nations by using the complex notion of word accent which combines stress, tone, and quantity.

Following his foundational study of Finnic gradation (1981b, see also section 2.5.), Viitso published a complete description and explanation of the nature of Livonian gradation (2007b). Livonian phonological structure does not show the general Finnic type of radical grade alternation, but it does show quantitative gradation. According to Viitso, the essence of Livonian gradation is a regular quantitative distinction of trochaic feet with strong-grade and weak-grade stressed syllables and subsequent unstressed syllables (e.g., lēbad [le:bat], 'bread, NPl', leibõ [lei:bə] 'bread, PSg'). He analysed the wide variety of alternations of weak- and strong-grade stems in inflection and established the main types of Livonian gradational paradigms.

Together with Hille Pajupuu, Viitso conducted a spectrographic study of Livonian polyphthongs (i.e., diphthongs and triphthongs, see Pajupuu \& Viitso 1986). In the Finnic language group, Livonian possesses the most complicated system of polyphthongs. This study dealt with the acoustic characteristics of polyphthong classes. The results of this experimental phonetic study support Viitso's analysis of Livonian phonology. The study also noted that much as for monophthongs, quantity is also distinctive for polyphthongs. An important result concerning Livonian word prosody was the claim that similarly to Estonian, there exists an inversely proportional relationship in Livonian between the vowels of the second and first syllable. In addition, the difference between polyphthongs with and without stød ${ }^{2}$ was described on the basis of F0, the quality of diphthongs, and the durational relations of the component parts of the polyphthongs.

Pajupuu's and Viitso's analysis showed that in terms of acoustics, Livonian stød can be characterised comparatively well by means of its F0 and intensity. The results reveal that there is a rapid increase in F0 in words with stød. Even in words where the drop in intensity associated with stød is absent, the specific rising-falling tone contour is present and invariably characterises these and other stød-words (see Figure 2).

2 Two tones occur in Livonian primary-stressed syllables: the plain (or rising) tone and the broken tone which is rising-falling and is sometimes accompanied by laryngealisation. The words with the plain and broken tone are also referred to as words without stød and words with stød (see Tuisk 2015 for details). The term stød is borrowed from Danish where there is a similar phenomenon. 

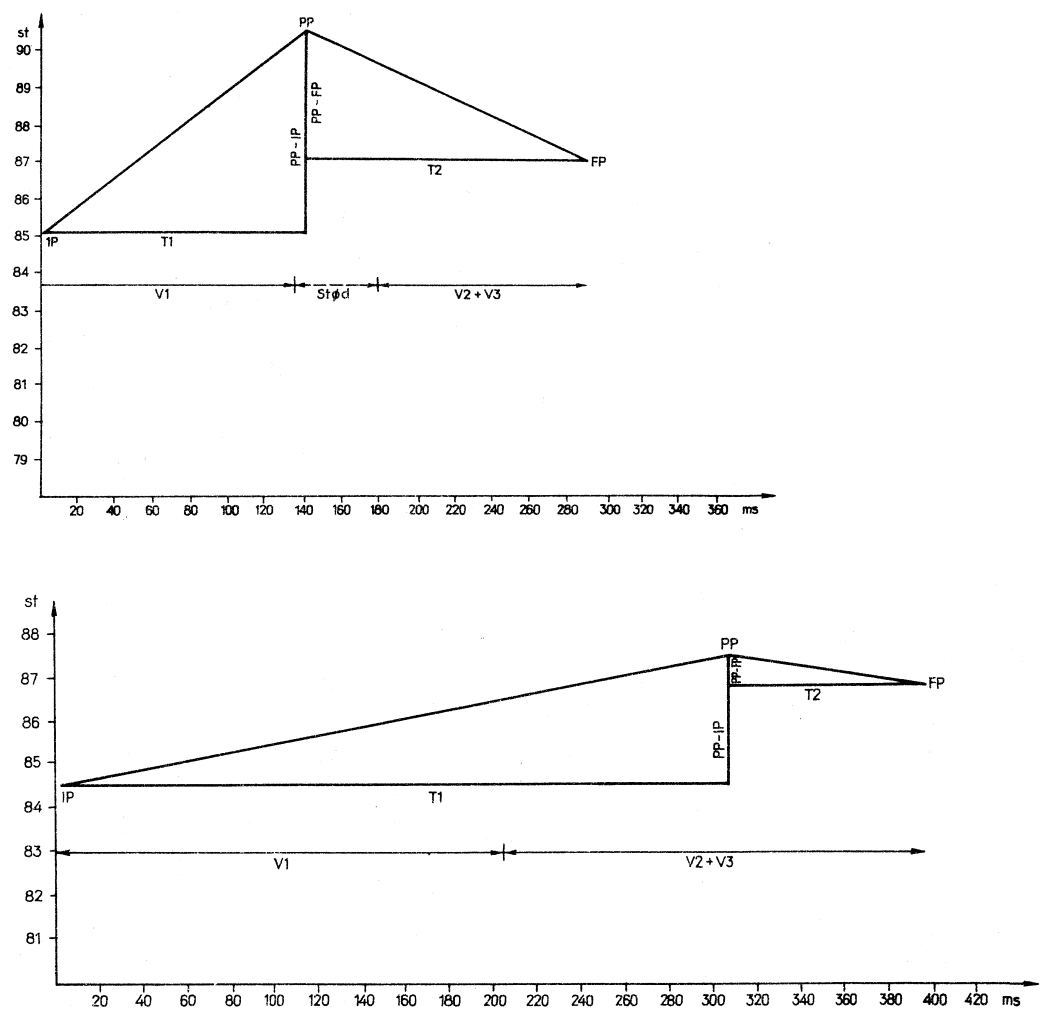

Figure 2. The tone contours of polyphthongs with and without stød (Pajupuu \& Viitso 1986: 108-109 and Viitso 2008a: 272273).

Viitso has compiled a survey of previous research on Livonian prosody (2007a). He also participated in the Finno-Ugric prosody project as the main expert on Livonian and co-author of a monographic study of Livonian prosody (Lehiste et al. 2008). The goal of this experimental phonetic study was to give an overview of the main prosodic characteristics of Livonian based on an acoustic analysis of the speech of eight Livonian speakers. Up to that point, Livonian had usually been described as having an opposition between short and long vowels in the stressed first syllable, which would suggest only a two-way opposition. However, previous studies had not looked at the durational ratios between syllables. It appeared that at the level of metric feet, Livonian has a ternary opposition similar to Estonian but it is achieved by different means. 


\subsection{Studies on Livonian grammar}

Following his analysis of Livonian verb forms (1983a), with every passing year Viitso moved closer to his goal of compiling an exhaustive description of the Livonian inflectional system. In 1999, Viitso's student Valts Ernštreits published his dictionary "Līvõkīel-leţkīel, leţkīellīvõkīel sõnārōntõz. Lībiešu-latviešu, latviešu-lībiešu vārdnīca" (Livonian-Latvian, Latvian- Livonian Dictionary, Ernštreit 1999). Viitso was a consultant for this book and also included tables of Livonian inflection types for nouns and verbs in this dictionary (Viitso 1999a, 1999b, 1999c, 1999d). Collaboration between Ernštreits and Viitso continued and in 2012 their monumental dictionary "Lìvõkīel-ēstikiel-leţkīel sõnārōntõz" (Livonian-Estonian-Latvian Dictionary, 2012a) appeared in print and also online in 2013 (see section 2.3.). In this dictionary, Viitso presented general descriptions of Livonian pronunciation and grammar as well as expanded tables of Livonian inflection types. This was the most detailed overview of the complicated Livonian inflection system ever presented.

Among the Finnic languages, Livonian has the most complex system of morphophonological alternation and also the greatest variety of optional suffixal variants. In his article on Livonian inflection classes (2012b), Viitso gives an overview of the inflectional forms in verbal and nominal paradigms, their suffixes, and also their morphophonological alternations. Taking into account all the possible variable suffixes and morphemic alternations, Viitso established 62 verb paradigm types and 238 nominal types in total. He arranged these types into classes and then established a minimal set of forms of classificatory significance. Livonian inflections had never previously been analysed at such a level of detail.

In recent years, Viitso has focused more on (morpho)syntax. He has analysed obligation, duty, and necessity in Livonian (2014a), which are expressed mainly using constructions containing the forms pidìm 'must' and pidīks 'should have to', or a finite form of the verbs tūlda 'to come', lä̀ 'dõ 'to go', vōlda 'to be', līdõ 'shall, will'. On the basis of Viitso's discussion and examples, the multitude of constructions can be reduced to eleven underlying constructional models consisting of three components: (1) the experiencer in the nominative or the experiencer in the dative (which can occur with all auxiliaries), (2) an auxiliary verb as the predicate, and (3) the infinitive, a supine form or a participle of a main verb, or the adverb vajāg 'necessary' and the object noun. 
Viitso co-authored an article about Livonian negation together with Helle Metslang and Karl Pajusalu (Metslang et al. 2015) for the comprehensive research project "Negation in the Uralic Languages". The main Livonian markers of negation are analysed in this study: (1) the forms of the negation verb, which are $\ddot{a} b$ in the indicative and conditional present, $i z$ in the indicative past, and ala in the imperative and the jussive; (2) mittõ which is used to reinforce negation and to mark the scope of the constituent negation; (3) the particle $\ddot{a} p$ that functions as a pro-sentence. This article notes that all verb categories which are expressed in affirmative verb forms can also appear as negative forms, although their expression is divided inconsistently between forms of the negation verb and lexical verb. The Livonian negation verb forms have given rise to negative prefixes, coordinating conjunctions, and a comparative marker.

In Livonian, there is a small set of words marking either location or time, which answer the questions where? (e.g., kuo'nnõ 'at home') and

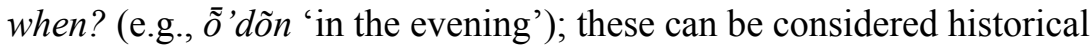
forms of the essive. One of Viitso's recent articles (2016a) analyses these forms in the context of the lative, sublative, and excessive case forms, which answer the questions to where? (kuo'ddon 'to home'), until when? (õ 'dõgon 'until the evening'), and from where? (e.g., kuo 'ndõ kuo'ndõst 'from home'), since when? (e.g., õ 'dõgst 'since the evening'), and the history of these forms.

The dative is an uncommon case in the Finnic language area and has long been discussed alongside the Finnish dative genitive. The Livonian dative case is used primarily for expressing a recipient or beneficiary, owner, or source, which in other Finnic languages would be expressed with the allative, adessive, or ablative. Viitso was recently the opponent of a dissertation on the Finnish dative genitive (Inaba 2015); the study compared it to the dative in Livonian and to the genitive in the possessive clauses in South Saami, Mordvin, and Mari (see Viitso's review 2016b).

\subsection{Studies on Livonian vocabulary}

One of Tiit-Rein Viitso's research approaches has been mapping the areal distribution of Finnic lexical items. As the primary expert on Livonian, he was actively involved in preparing the linguistic atlas of the Finnic languages "Atlas Linguarum Fennicarum" (ALFE I-III 20042010). Approximately fifty distribution maps were prepared by Viitso 
and include his comments, which testify to his comprehensive in-depth knowledge of the Finnic languages (Hänninen et al. 2004, 2007, 2010; Viitso was the main editor of ALFE II).

As already noted above, a collection of Viitso's studies on the Livonian language and Finnic linguistic landscapes was published in 2008, and the comprehensive Livonian dictionary "Līvõkīel-ēstikīel-leţkīel sõnārōntõz" (Viitso 2012a), compiled together with Valts Ernštreits, was published in 2012. Viitso's long-term work on the dictionary began already in the 1970s with his outstanding consultant Katrin Krason. She and Livonian school teacher Pētõr Damberg were the most valuable consultants for Viitso while the dictionary was being compiled (see also sections 2.5. and 2.6.).

Along with larger topics, Viitso has also focussed on smaller issues relating to vocabulary items that have drawn his attention. He has published several articles on Livonian words and expressions (1990a, 1993a, 1993b, 1995a, postscripts presented in 2008a). For example, he analysed the phrase neitsõ kuolm pi'nnñ 'the maiden's three dogs' (1990a), which consists of three extremely interesting words. He discussed Livonian kõps 'hare' in comparison with Finnic *korva 'ear', which has no direct source in modern Livonian (1993a). He also analysed Livonian i'gmõd 'gums' in one of his papers (1993b) and also the etymology of Livonian miez and Veps meź in another study (1995a).

Viitso has always been active in discussing and commenting on various linguistics topics with other linguists. In 1990, he published his thoughts on the shared vocabulary of Estonian and Livonian (1990b).

\subsection{Surveys of Livonian and its dialects}

Following decades of active fieldwork, Viitso has put together a number of overviews of Livonian. His survey of Livonian published in Russian (1993c) was followed by significant articles also in Estonian and Latvian. A comprehensive collection of studies on the Livonians and their language and culture was published ("Liivlased. Ajalugu, keel ja kultuur" [The Livonians. History, language, and culture], 2011) on the occasion of 2011 being recognised as the International Year of Livonian Language and Culture. Viitso compiled a detailed overview of the Livonian language (Viitso 2011) for this volume. This study also appeared in Latvian (Vìtso 2013) when this monumental book was translated into Latvian in 2013 ("Lībieši. Vēsture, valoda un kultūra" [The Livonians. History, language, and culture]). Both of Viitso's surveys describe the 
main features of Livonian, including its alphabet, sound system, gradation, and morphology. An introduction into Livonian dialects is followed by sample texts from West Livonian (Lūž village), East Livonian (Sīkrõg village), and Īra village, which is located at the dialect boundary between East and West Livonian. The Livonian of İra village has sometimes been considered a transitional or Central Livonian dialect, as it incorporates features of both major dialects of Courland Livonian.

Viitso is the first scholar who has thoroughly analysed the uncertain position of the Central or İra dialect of Courland Livonian (1999e). The main dialectal difference within Courland Livonian lies between its East and West dialects. It has been suggested that the Livonian of İra village forms a transitional or Central Livonian dialect (e.g., Posti 1942: XIV). In his analysis, Viitso discusses the various features that have been claimed to set apart the dialect of İra village. Based on a comparison with the other Livonian dialects, as well as historical developments, he suggests that Central Livonian is closer to East Livonian and does not constitute a third main dialect of Courland Livonian, and therefore it would be appropriate to define it just as the İra dialect.

\subsection{Livonian and the history of the Finnic languages}

In addition to his studies on the structure of the Finnic languages, Viitso's research interests have also included the earliest history of the Finnic languages and language contacts as well as the historical formation of the Finnic languages. He has always emphasised that each language should be viewed in a broader perspective, one that does not omit the historical and areal points of view.

Courland Livonian has had long-lasting contacts with the neighbouring Courland Latvian and Saaremaa North Estonian dialects, and to some extent also German and Ruhnu Swedish. However, Livonian also has a set of less noticeable innovations which it has in common with different related languages and dialects. In addition, Livonian vocabulary contains words that show resemblance to languages that do not belong to the direct contact area of Courland Livonian. These influences are at the focus of Viitso's study on the possible prehistoric contacts of Livonian (1998). He notes three possible explanations for such cases: (1) prehistoric contacts, (2) similar typological preconditions, and (3) an accidental resemblance with a particular term present in another language.

Viitso's analysis of the history of the first-syllable Finnic $\tilde{o}$ (1978, 2008a) is one-of-a-kind. Analysing the emergence of $\tilde{o}$ in the Southern 
Finnic languages, he finds its history more complicated than traditionally suggested. The detailed discussion on the genesis and development of $\tilde{o}$ is followed by differentiating 7 periods or phases of its development, including in Livonian.

Before turning his attention to Livonian quantitative gradation, Viitso gives a detailed overview of Finnic gradation, its types, and genesis (1981b, see Viitso 2008a for the Estonian version "Läänemeresoome astmevaheldus: tüübid ja tekkimine" [Finnic gradation: its types and origin]). He proposes that Finnic gradation was not derived from the Finnic proto-language, but instead developed when dialect differences already existed.

Viitso has always been interested in language and dialect classification. The problems of classifying the Finnic languages and their main dialects are discussed in many of his works (e.g., 1985, Viitso's later postscript is available in Viitso 2008a). In his presentation and article on the eastern boundary of Finnic (2003b), Viitso discusses the relationships of the main Finnic dialects with a focus on the Eastern Finnic dialects.

In the largest collection of Viitso's studies "Liivi keel ja läänemeresoome keelemaastikud" (2008a), a survey of the specific features of Livonian in the Finnic language space ("Liivi keele erijooned läänemeresoome keeleruumis" [The unique features of Livonian in the Finnic language space, 2008b) is published for the first time. In its seven chapters, Viitso gives a detailed overview of Courland Livonian, its dialects, alphabet, and sound system. Next he presents detailed descriptions of Livonian morphology, morphophonology, and syntax.

Tiit-Rein Viitso also published a comparative study of Livonian and Leivu South Estonian (2009). First, he explained the etymology of the names of the Livonians and Leivus and rejects the traditional Estonianbased etymology. He suggests that the common stem for the Livonians and Leivus most likely comes from an unattested Old Norse name given for Livonia by the Scandinavians. It was later borrowed into Livonian and Leivu from German. In addition, Viitso focusses on five shared phonetic innovations in Livonian and Leivu. Namely, (1) the breaking of long and short mid-vowels into long and short diphthongs, (2) triphthongs, (3) the loss of intervocalic * $h$ after short initial syllables and the rise of the broken tone, (4) the development of prepalatal sibilants $\check{s}$ and $\check{z}$, and finally, (5) the rise of voiced obstruents.

There are not many in-depth scientific writings written in Livonian. In 1978 an outstanding article from Viitso's consultant Pētõr Damberg 
about Livonian language planning was published in both Estonian and Livonian (Damberg 1978a, 1978b). Much as Damberg, Viitso was very serious about writing for the Livonians in the Livonian language. He is the only researcher who has described the position of the Livonian language in the Finnic language family in Livonian (in the article "Livoõkēl munt vāldamiersūomõ kīeld siegās" \{Livonian among the other Finnic languages], 1994a).

The position of the Livonians and the Livonian language is also studied in the context of the other Finnic languages in many of his other articles: "Läänemeresoomlased: maahõive ja varaseimad kontaktid" (The Finnic peoples: Expansion and earlier contacts, 1983b), "On the earliest Finnic and Balto-Slavic Contacts" (1990c), "Finnic and its prehistoric Indo-European neighbors" (1992), "Eteläiset itämerensuomalaiset kielet eilen ja tänään" (The Southern Finnic languages yesterday and today, 1993d), "Possible reflections of the prehistoric Amber Way in modern languages" (1994b), "Finnic affinity" (2000).

\subsection{Writings on Livonian culture, folklore, and people}

There is a part of Tiit-Rein Viitso's writings that are not classified as strictly scientific studies, but rather scientific surveys. He has written overviews of several remarkable books as well as articles about people who have excelled in their life's work.

The most comprehensive Livonian grammar to date remains Ferdinand Johann Wiedemann's “Joh. Andreas Sjögren's Livische Grammatik nebst Sprachproben“"(Joh. Andreas Sjögren's Livonian Grammar with language samples) published in 1861. Viitso's analysis (1996) has shown, however, that while the materials and introduction of the book are from Sjögren, the compilation of the grammar was entirely Wiedemann's work.

In 2007, a Livonian album was discovered, which documents the swan song of this nation's life on its native coast. Tiit-Rein Viitso received the original album in 2005 and describes its miraculous discovery in his comments on the album $\left(2007 \mathrm{c}, 2007 \mathrm{~d}^{3}\right)$. The album was originally created by Pizā school principal Pētõr Damberg and his pupils in the 1930s. It is not completely known how the original found its way to Tartu, but it was Kaarel Kotsar - a Tartu school director and mayor of

3 In Latvia, the Livs and the Liv language are traditionally used for the Livonians and the Livonian language. 
the city, and later Vice-Rector of the Tallinn Pedagogical Institute - who managed to save the album from burning during the Soviet occupation.

Viitso has also introduced people without any specific linguistic background to outstanding works written on Livonian. In 2009, a major dictionary of Salaca Livonian appeared in print (compiled by Eberhard Winkler and Karl Pajusalu, 2009). In his review of this dictionary (2010a), Viitso explains the historic background of Salaca Livonian and the significance of the dictionary.

Viitso is the co-author of a two-part book about Livonian proverbs (Mälk 1981). He was the main editor of its Livonian language portions and the compiler of its word list. In 1995, Viitso published a separate article about Livonian proverbs (1995b).

For researchers of endangered languages, the importance of recording the last speakers of these languages is understandable without requiring further explanation. Viitso has actively visited and recorded Livonians in his fieldwork over the last decades. He warmly remembers the Estonian Language Institute where he worked during these years and which made it possible for him to visit Latvia at any time he wished (Viitso 2008a: 14). In 2002, a CD of Livonian texts spoken by native Livonians was released. The CD consists of digitised recordings from the Estonian Language Institute's archives. On this occasion, Viitso (2002) drew readers' attention to the importance of digitising all old Livonian recordings.

Viitso's writings reveal his empathy, care, and concern towards the Livonians as well as the Livonian language, folklore, culture, and also researchers of Livonian. One of his consultants and friends was East Livonian speaker Pētõr Damberg. Viitso honoured Damberg on the speaker's 70th birthday (1979) and memorialised him following his death (1987). On the 80th anniversary of the founding of Livord $\bar{I} t$ (the Livonian Union), Viitso published an overview of the Livonians, the Livonian language, and Livonian studies (2003a). Upon their passing, he has written warm farewells dedicated to his friends who studied and analysed Livonian along with him - Seppo Tapio Suhonen (2010b), Tõnu Karma (2014b), and Kalevi Wiik (2015). They were his companions and colleagues on a journey of discovery through the Livonian world. 


\section{Conclusion}

There are few other linguists whose interest in Livonian is as heartfelt or which has been pursued with such a depth of scientific curiosity. This highly endangered southernmost Finnic language has been TiitRein Viitso's research area for most of the years of his academic career.

In his Livonian research, Viitso has focussed on various topics, including pronunciation, gradation, the historical contacts of Livonian with other languages, its vocabulary, grammar, etc. As a phonologist, his favourite subject has been Livonian phonology in the broader Finnic context. As a result of his work, he has produced the most comprehensive and detailed classification of Livonian verbal and nominal inflection types to date. He has also described and explained various phenomena found in Livonian syntax and morphosyntax.

Tiit-Rein Viitso has long been well-known and warmly welcomed in the Livonian community, whether by linguists or Livonian descendants. His advice and knowledge have always been and continue to be highly valued.

\section{Addresses:}

Tuuli Tuisk

Institute of Estonian and General Linguistics

University of Tartu

Jakobi 2-409

51005 Tartu, Estonia

E-mail: tuuli.tuisk@ut.ee

Karl Pajusalu

Institute of Estonian and General Linguistics

University of Tartu

Jakobi 2-425

51005 Tartu, Estonia

E-mail: karl.pajusalu@ut.ee 


\section{References}

Blumberga, Renāte, Tapio Mäkeläinen, and Karl Pajusalu, eds. (2011) Liivlased. Ajalugu, keel ja kultuur. Tallinn: Eesti Keele Sihtasutus.

Blumberga, Renāte, Tapio Mekeleinens, and Karls Pajusalu, eds. (2013) Lìbieši Vēsture, valoda un kultūra. Rīga: Līvõ Kultūr sidām.

Damberg, Pētõr (1978a) “Liivi keelekorraldusest”. Emakeele Seltsi aastaraamat 23, 1977, 71-82.

Damberg, Pētõr (1978b) "Līvõ kīel kõrdõlpanmi”. Emakeele Seltsi aastaraamat 23, 1977, 83-92.

Ernštreit, Valt (1999) Lìvõkiel-leţkīel, leţkiel-līvõkīel sõnārōntõz. Lībiešu-latviešu, latviešu-lībiešu vārdnīca. Rīga: Līvõ Kultūr sidām.

Hänninen, Anneli, Arvo Laanest, Helmi Neetar, Vilja Oja, Vladimir Rjagojev, Seppo Suhonen, Tuomo Tuomi, Ulla Vanhatalo, Tiit-Rein Viitso and Nina Zaitseva (2007) Atlas Linguarum Fennicarum. Itämerensuomalainen kielikartasto. Läänemeresoome keeleatlas. Ostseefinnischer Sprachatlas. Лингвистический атлас прибалтийскофинских языков. (ALFE, 2.) Helsinki: Suomalaisen kirjallisuuden seura; Kotimaisten kielten tutkimuskeskus.

Hänninen, Anneli, Raimo Jussila, Helmi Neetar, Vilja Oja, Vladimir Rjagojev, Seppo Suhonen, Tuomo Tuomi, Tiit-Rein Viitso, and Nina Zaitseva (2010) Atlas Linguarum Fennicarum. Itämerensuomalainen kielikartasto. Läänemeresoome keeleatlas. Ostseefinnischer Sprachatlas. Лингвистический атлас прибалтийскофинских языков. (ALFE, 3.) Helsinki: Suomalaisen Kirjallisuuden Seura.

Hänninen, Anneli, Raimo Jussila, Lilja Kirppu, Arvo Laanest, Heikki Leskinen, Helmi Neetar, Vilja Oja, Vladimir Rjagojev, Seppo Suhonen, Tuomo Tuomi, Ulla Vanhatalo, Tiit-Rein Viitso, and Nina Zaitseva (2004) Atlas Linguarum Fennicarum. Itämerensuomalainen kielikartasto $=$ Läänemeresoome keelteatlas $=$ Ostseefinnischer Sprachatlas = Лингвистический атлас прибалтийско-финских языков. (ALFE, 1.) Helsinki: Suomalaisen kirjallisuuden seura; Kotimaisten kielten tutkimuskeskus.

Inaba, Nobufumi (2015) Suomen datiivigenetiivin juuret vertailevan menetelmän valossa. Turun yliopisto. (Mémoires de la Société Finno-Ougrienne, 272.) Helsinki: Suomalais-Ugrilainen Seura.

LA $2018=$ Lìvlizt āigastrōntõz. Lībiešu gadagrāmata 2018. Līvu (Lībiešu) savienība "Līvõd İt".

Lehiste, Ilse, Pire Teras, Valts Ernštreits, Pärtel Lippus, Karl Pajusalu, Tuuli Tuisk, and Tiit-Rein Viitso (2008) Livonian prosody. Helsinki: Suomalais-ugrilainen seura.

Mälk, Vaina, Pētõr Damberg, Elza Kokare, Arvo Krikmann, Lembit Vaba, Tiit-Rein Viitso, ja Eduard Vääri (1981) Liivi vanasõnad eesti, vadja ja läti vastetega. 2 vols. A. Krikmann, V. Mälk, and T.-R. Viitso, eds. Tallinn: Eesti Raamat.

Metslang, Helle, Karl Pajusalu, and Tiit-Rein Viitso (2015) “Negation in Livonian”. In Matti Miestamo, Anne Tamm, and Beáta Wagner-Nagy, eds. Negation in Uralic languages, 433-456. (Typological Studies in Language, 108.) Amsterdam: Benjamins. 
Pajupuu, Hille and Tiit-Rein Viitso (1986) "Livonian polyphthongs". In Arvo Eek, ed. Estonian Papers in Phonetics 1984-1985, 96-130. Tallinn.

Posti, Lauri (1942) Grundzüge der livischen Lautgeschichte. (Mémoires de la Société Finno-Ougrienne, 85.) Helsinki.

Tuisk, Tuuli (2015) Livonian word prosody. Doctoral Dissertation. Tartu: University of Tartu Press.

Viitso, (1961) "Vadja keele Luutsa-Liivtšülä murraku fonoloogia”. Emakeele Seltsi aastaraamat 7, 142-174.

Viitso, Tiit-Rein (1974) “On the phonological role of stress, quantity, and stød in Livonian”. Sovetskoe finno-ugrovedenie 10, 3, 159-170.

Viitso, Tiit-Rein (1975) “Outlines of Livonian phonology”. Symposion Phonologische Analyse der uralischen Sprachen. Berlin, 17.-20. September 1974, 83-113. (Linguistische Studien. Reihe A. Arbeitsberichte, 22.) Berlin: Akademie der Wissenschaften der DDR, Zentralinstitut für Sprachwissenschaft.

Viitso, Tiit-Rein (1978) "Läänemeresoome esimese silbi õ ajalugu”. Keel ja struktuur 10, 81-117. Tartu.

Viitso, Tiit-Rein (1979) "Pētõr Damberg 70". Sirp ja Vasar, 10 (1837), 5.

Viitso, Tiit-Rein (1981a) Lä̈̈nemeresoome fonoloogia küsimusi. Tallinn: ENSV TA Keele ja Kirjanduse Instituut.

Viitso, Tiit-Rein (1981b) "Finnic gradation: types and genesis". Sovetskoe finnougrovedenie 17, 3, 176-185.

Viitso, Tiit-Rein (1983a) “Two analyses of Livonian verb forms”. Symposium on Grammars of Analysis and Synthesis and Their Representation in Computational Structures. Tallinn, November 28-30, 1983. Summaries, 116-120. Tallinn.

Viitso, Tiit-Rein (1983b) "Läänemeresoomlased: maahõive ja varaseimad kontaktid". Symposium saeculare Societatis Fenno-Ugricae, 265-281. (Suomalais-Ugrilaisen Seuran Toimituksia, 185.) Helsinki.

Viitso, Tiit-Rein (1985) "Läänemeresoome murdeliigenduse põhijooned". Keel ja Kirjandus 28, 7, 399-404.

Viitso, Tiit-Rein (1987) "Pētõr Damberg". Edasi, 101 (11328).

Viitso, Tiit-Rein (1990a) "Livonian neitsõ kuolm pi’ņño". Linguistica Uralica 26, 4, $247-250$.

Viitso, Tiit-Rein (1990b) "Kommenttipuheenvuoro Eino Koposen esitelmään Viron ja liivin yhteissanaston tarkastelua". Itämerensuomalaiset kielikontaktit. Itämerensuomalainen symposium 7. kansainvälisessä fenno-ugristikongressissa Debrecenissä 27.8.-1.9.1990, 40-43. (Kotimaisten kielten tutkimuskeskuksen julkaisuja, 61.) Helsinki.

Viitso, Tiit-Rein (1990c) "On the earliest Finnic and Balto-Slavic Contacts”. Itämerensuomalaiset kielikontaktit. Itämerensuomalainen symposium 7. kansainvälisessä fenno-ugristikongressissa Debrecenissä 27.8.-1.9.1990, 140-147. (Kotimaisten kielten tutkimuskeskuksen julkaisuja, 61.) Helsinki.

Viitso, Tiit-Rein (1992) "Finnic and its prehistoric Indo-European neighbors". Finnischugrische Sprachen zwischen dem germanischen und dem slavischen Sprachraum. Vorträge des Symposiums aus Anlaß des 25-jährigen Bestehens der Finnougristik 
an der Rijksuniversiteit Groningen 13.-15. November 1991, 185-196. Amsterdam and Atlanta, GA: Rodopi.

Viitso, Tiit-Rein (1993a) "Livonian kõps 'hare' and Finnic *korva 'ear"'. Linguistica Uralica 29, 2, 89-94.

Viitso, Tiit-Rein (1993b) “Livonian i'gmõd 'gums"”. Linguistica Uralica 29, 3, 173 175.

Viitso, Tiit-Rein (1993c) “Livskij jazyk”. Jazyki mira. Ural’skie jazyki, 76-90. Moscow: Nauka.

Viitso, Tiit-Rein (1993d) “Eteläiset itämerensuomalaiset kielet eilen ja tänään”. In Tapani Salminen, ed. Uralilaiset kielet tänään. Mikko Korhosen muistosymposiumin 14.10.1992 esitelmät, 59-65. (Snellmaninistituutin julkaisuja, A 13/1993.) Kuopio.

Viitso, Tiit-Rein (1994a) "Līvõkēḷ munt vāldamiersūomõ kīeld siegās". Lībieši. Rakstu krājums, 249-257. Rīga: Zinātne.

Viitso, Tiit-Rein (1994b) "Possible reflections of the prehistoric Amber Way in modern languages”. In Janos Pusztay, ed. Das sprachliche Bild der Bernsteinstraße, 104110. Szombathely: Savaria University Press.

Viitso, Tiit-Rein (1995a) "Livonian mīez, Veps meź”. Linguistica Uralica 31, 1, 14-16.

Viitso, Tiit-Rein (1995b) "Liivi vanasõnu”. Minor Uralic languages: Grammar and Lexis, 193-200. Tartu and Groningen.

Viitso, Tiit-Rein (1996) "Ferdinand Johann Wiedemann ja 135-aastane liivi grammatika". Fenno-Ugristica 19, 154-157.

Viitso, Tiit-Rein (1998) "Possible prehistoric contacts of Livonian". Linguistica Uralica $34,1,8-22$.

Viitso, Tiit-Rein (1999a) "Deklinējamo vārdu locīšanas tipu tabula". In Valt Ernštreit, ed. Lìvõkiel-leţkieel-līvõkiel sõnārōntõz. Lībiešu-latviešu-lībiešu vārdnīca, 96-101. Rīgõ.

Viitso, Tiit-Rein (1999b) “Deklinējamo vārdu galotnes”. In Valt Ernštreit, ed. Lìvõkīelleţkiel-līvõkiel sõnārōntõz. Lībiešu-latviešu-lībiešu vārdnīca, 102-105. Rīgõ.

Viitso, Tiit-Rein (1999c) "Darbības konjugēěanas tipu tabulas". In Valt Ernštreit, ed. Lìvõkiel-leţkiel-līvõkīel sõnārōntõz. Lībiešu-latviešu-lībiešu vārdnīca, 106-108. Rīgõ.

Viitso, Tiit-Rein (1999d) “Darbības vārdu galotņu tabula”. In Valt Ernštreit, ed. Lìvõkīelleţkiel-līvõkiel sõnārōntõz. Lībiešu-latviešu-lībiešu vārdnīca, 108-109. Rīgõ.

Viitso, Tiit-Rein (1999e) “Keskliivi”. In Karl Pajusalu and Tõnu Tender, eds. Õdagumeresoomõ veeremaaq. Läänemeresoome perifeeriad, 158-169. (Publications of Võro Institute, 6.) Võro: Võro Instituut.

Viitso, Tiit-Rein (2000) "Finnic affinity". In Anu Nurk, Triinu Palo, and Tõnu Seilenthal, eds. Congressus Nonus Internationalis Fenno-Ugristarum 7.-13.8.2000 Tartu. Pars I: Orationes plenariae \& Orationes publicae, 153-178. Tartu.

Viitso, Tiit-Rein (2002) "Sammuke liivi keele igavikustamise poole". Sirp 19.04.2002. Viitso, Tiit-Rein (2003a) "Lībieši, lībiešu valoda un lībiešu valodas izpēte. Līvõd, līvõ kēḷ ja līvõ kīel tuņšlimi. Livonians, Livonian language, Livonian Studies". Lìvõd İt 80, 1923-2003, 7-9. 
Viitso, Tiit-Rein (2003b) “Läänemeresoome idapiir”. In Karl Pajusalu and Jan Rahman, eds. Õdagumeresoomõ hummogupiir. Lä̈̈nemeresoome idapiir, 11-28. (Publications of Võro Institute, 15). Võro: Võro Instituut.

Viitso, Tiit-Rein (2007a) "Survey of previous research on Livonian prosody". Linguistica Uralica 43, 1, 23-28.

Viitso, Tiit-Rein (2007b) "Livonian gradation: types and genesis". Linguistica Uralica $43,1,45-62$.

Viitso, Tiit-Rein (2007c) “Album tulāb tāgiž kuodāj”. Lìvõd jelāmi. The life of Livs, 5. Rīgõ: Līvõ Kultūr Sidām, Neputns.

Viitso, Tiit-Rein (2007d) “The album returns home". Lìvõd jelāmi. The life of Livs, 5-6. Rīgõ: Līvõ Kultūr Sidām, Neputns.

Viitso, Tiit-Rein (2008a) Liivi keel ja läänemeresoome keelemaastikud. Tartu-Tallinn: Eesti Keele Sihtasutus.

Viitso, Tiit-Rein (2008b) "Liivi keele erijooned läänemeresoome keeleruumis". Liivi keel ja läänemeresoome keelemaastikud, 308-355. Tartu-Tallinn: Eesti Keele Sihtasutus.

Viitso, Tiit-Rein (2009) "Livonian and Leivu: shared innovations and problems". Linguistica Uralica 45, 4, 269-282.

Viitso, Tiit-Rein (2010a) "Salatsiliivi sõnaraamat". Oma Keel 2, 104-107.

Viitso, Tiit-Rein (2010b) "Seppo Tapio Suhonen (1938-2010)". Linguistica Uralica $46,4,313-315$.

Viitso, Tiit-Rein (2011) "Liivi keele põhijooned". In Renāte Blumberga, Tapio Mäkeläinen, and Karl Pajusalu, eds. Liivlased. Ajalugu, keel ja kultuur, 203-217. Tallinn: Eesti Keele Sihtasutus.

Viitso, Tiit-Rein (2012b) "Concerning inflection classes in Livonian". Linguistica Uralica 48, 1, 12-26.

Viitso, Tiit-Rein (2014a) “Constructions of obligation, duty, and necessity in Livonian". Journal of Estonian and Finno-Ugric Linguistics 5, 1, 193-214.

Viitso, Tiit-Rein (2014b) “In memoriam. Tõnu Karma (1. V 1924-9. IX 2014)”. Keel ja Kirjandus 11, 893-895.

Viitso, Tiit-Rein (2015) "In memoriam Kalevi Wiik (2.VIII 1932-12.IX 2015)". Keel ja Kirjandus 12, 901-903.

Viitso, Tiit-Rein (2016a) "The Essive in Livonian". Journal of Estonian and FinnoUgric Linguistics 7, 1, 145-175.

Viitso, Tiit-Rein (2016b) "Der finnische Dativgenetiv auf der Basis des wolgafinnischen Genitivs (Nobufumi Inaba: Suomen datiivigenetiivin juuret vertailevan menetelmän valossa)". Finnisch-Ugrische Forschungen 63, 1-3.

Viitso, Tiit-Rein (Vijtso, Tijt-Rejn) (1966) Opisanie plana vyraženija prionežskogo dialekta vepsskogo jazyka. Avtoreferat dissertacii na soiskanie učenoj stepeni kandidata filologičeskix nauk. Tartu.

Viitso, Tiit-Rein (Vītso, Tīts Reins) (2013) “Lībiešu valodas pamatiezīmes”. In Renāte Blumberga, Tapio Mekeleinens, Karls Pajusalu, eds. Lībieši. Vēsture, valoda un kultūra, 267-286. Rīga: Līvõ Kultūr sidām. 
Viitso, Tiit-Rein; Ernštreits, Valts (2012a) Lìvõkīel-ēstikīel-lețkīel sõnārōntõz. Liivieesti-läti sõnaraamat. Lībiešu-igaunu-latviešu vārdnīca. Tartu and Rīga: Tartu Ülikool and Latviešu valodas aǵentūra.

Winkler, Eberhard; Pajusalu, Karl (2009) Salis-Livisches wörterbuch. (Linguistica Uralica. Supplementary series, Vol. 3.) Tallinn: Teaduste Akadeemia Kirjastus.

Kokkuvõte. Tuuli Tuisk, Karl Pajusalu: Uurimisreis läbi liivi maailma: Tiit-Rein Viitso uurimused. Artiklis antakse ülevaade emeriitprofessor TiitRein Viitso liiviteemalistest uurimustest. Liivi keel on olnud Viitsole paeluvamaid keeli juba üle 50 aasta. Liivi keelt on ta uurinud kõige erinevamatest aspektidest. Artiklis on Viitso liivi uurimusi vaadeldud kuues suures rühmas, milleks on uurimused (1) liivi hääldusest ja sõnaprosoodiast, (2) liivi grammatikast, (3) sõnavarast; lisaks ülevaated (4) liivi keelest, (5) liivi keelest läänemeresoome kontekstis, (6) liivi folkloorist, kultuurist ja inimestest.

Märksõnad: Tiit-Rein Viitso, läänemeresoome keeled, liivi keel, uurimisajalugu

Kubbõvõttõks. Tuuli Tuisk, Karl Pajusalu: Tuṇšlimiz reiz leb līvõd mōīlma: Tiit-Rein Viitso tuṇšlimizt. Kēras āt vaņţõltõd profesor Tiit-Rein Viitso līvõkīel tuņšlimiz tīed. Lìvõ kēl um vỏnd Viitso pierāst ikš amā interesant kēl jemīn äbku 50 àigastõ. Ta um tuņšlõn līvõ kīeldõ setmin aspektist. Sies kēras Viitso tuņšlimiztīed at jagdõd kūdõ gruppõ: (1) līvõ kīel īeldimi ja sõnād prozodij, (2) līvõ kīel gramatik, (3) līvõ sõnād, (4) iḷammizt kērad iḷ līvõ kīel, (5) līvõ kēl vāldamiersūomõ kīeld siegās, (6) līvõ folklōr, kultūr ja rovst. 


\section{Appendix}

\section{Tiit-Rein Viitso's Livonian Bibliography}

\section{4}

Viitso, Tiit-Rein (1974) "On the phonological role of stress, quantity, and stød in Livonian”. Sovetskoe finno-ugrovedenie 10, 3, 159-170.

1975

Viitso, Tiit-Rein (1975) "Outlines of Livonian phonology”. Symposion Phonologische Analyse der uralischen Sprachen. Berlin, 17.-20. September 1974, 83-113. (Linguistische Studien. Reihe A. Arbeitsberichte, 22.) Berlin: Akademie der Wissenschaften der DDR, Zentralinstitut für Sprachwissenschaft.

1979

Viitso, Tiit-Rein (1979) “Pētõr Damberg 70". Sirp ja Vasar (8. märts) 39, 10 (1837), 5.

\section{1}

Viitso, Tiit-Rein (1981) Läänemeresoome fonoloogia küsimusi. Tallinn: ENSV TA Keele ja Kirjanduse Instituut.

Liivi vanasõnad eesti, vadja ja läti vastetega. I-II. (1981) Koostanud Vaina

Mälk Pētõr Dambergi, Elza Kokare, Arvo Krikmanni, Lembit Vaba, TiitRein Viitso ja Eduard Vääri osavõtul. Arvo Krikmann, Vaina Mälk ja TiitRein Viitso toim. Tallinn: Eesti Raamat.

\section{3}

Viitso, Tiit-Rein (1983) "Two analyses of Livonian verb forms". Symposium on Grammars of Analysis and Synthesis and Their Representation in Computational Structures. Tallinn, November 28-30, 1983. Summaries, 116-120. Tallinn.

\section{6}

Pajupuu, Hille and Tiit-Rein Viitso (1986) “Livonian polyphthongs". In Arvo Eek, ed., Estonian Papers in Phonetics 1984-1985, 96-130. Tallinn.

\section{7}

Viitso, Tiit-Rein (1987) “Pētõr Damberg”. Edasi (30. Aprill) 101 (11328).

\section{0}

Viitso, Tiit-Rein (1990) “Livonian neitsõ kuolm pi'ņnูȭ". Linguistica Uralica 26, 4, 247-250.

Viitso, Tiit-Rein (1990) "Kommenttipuheenvuoro Eino Koposen esitelmään Viron ja liivin yhteissanaston tarkastelua". Itämerensuomalaiset kielikontaktit. Itämerensuomalainen symposium 7. kansainvälisessä fenno-ugristikongressissa Debrecenissä 27.8.-1.9.1990, 40-43. (Kotimaisten kielten tutkimuskeskuksen julkaisuja, 61.) Helsinki. 
32 Tuuli Tuisk, Karl Pajusalu

\section{3}

Viitso, Tiit-Rein (1993) “Livonian kõps 'hare' and Finnic *korva 'ear'”. Linguistica Uralica 29, 2, 89-94.

Viitso, Tiit-Rein (1993) "Livonian i'gmõd 'gums"'. Linguistica Uralica 29, 3, 173-175.

Viitso, Tiit-Rein (1993) “Livskij jazyk”. Jazyki mira. Ural'skie jazyki, 76-90. Moscow: Nauka.

\section{4}

Viitso, Tiit-Rein (1994) "Līvõkēḷ munt vāldamiersūomõ kīeld siegās”. Lībieši. Rakstu krājums, 249-257. Rīga: Zinātne.

\section{5}

Viitso, Tiit-Rein (1995) “Livonian mīez, Veps meż”. Linguistica Uralica 31, 1, $14-16$.

Viitso, Tiit-Rein (1995) “Liivi vanasõnu”. Minor Uralic languages: grammar and lexis, 193-200. Tartu and Groningen.

\section{6}

Viitso, Tiit-Rein (1996) "Ferdinand Johann Wiedemann ja 135-aastane liivi grammatika”. Fenno-Ugristica 19, 154-157. Tartu.

\section{8}

Viitso, Tiit-Rein (1998) “Possible prehistoric contacts of Livonian”. Linguistica Uralica 34, 1. 8-22.

\section{9}

Viitso, Tiit-Rein (1999) "Deklinējamo vārdu locīšanas tipu tabula". In Valt Ernštreit, ed. Lìvõkīel-leţkīel-līvõkīel sõnārōntõz. Lībiešu-latviešu-lībiešu vārdnīca, 96-101. Rīgõ.

Viitso, Tiit-Rein (1999) “Deklinējamo vārdu galotnes”. In Valt Ernštreit, ed. Lìvõkiel-lețkīel-līvõkīel sõnārōntõz. Lībiešu-latviešu-lībiešu vārdnīca, 102105. Rīgõ.

Viitso, Tiit-Rein (1999) “Darbības konjugēšanas tipu tabulas". In Valt Ernštreit, ed. Līvõkīel-leţkīel-līvõkīel sõnārōntõz. Lībiešu-latviešu-lībiešu vārdnīca, 106-108. Rīgõ.

Viitso, Tiit-Rein (1999) "Darbības vārdu galotņu tabula". In Valt Ernštreit, ed. Līvõkīel-leţkīel-līvõkīel sõnārōntõz. Lībiešu-latviešu-lībiešu vārdnīca, 108-109. Rīgõ.

Viitso, Tiit-Rein (1999) “Keskliivi”. In Karl Pajusalu and Tõnu Tender, eds. Õdagumeresoomõ veeremaaq. Läänemeresoome perifeeriad, 158-169. (Publications of Võro Institute, 6.) Võro: Võro Instituut.

\section{2}

Viitso, Tiit-Rein (2002) "Sammuke liivi keele igavikustamise poole". Sirp 19.04.2002. 


\section{3}

Viitso, Tiit-Rein (2003) “Lībieši, lībiešu valoda un lībiešu valodas izpēte. Līvõd, līvõ kēḷ ja līvõ kīel tunšslimi. Livonians, Livonian language, Livonian studies". Lìvõd İt 80, 1923-2003, 7-9.

\section{7}

Viitso, Tiit-Rein (2007) "Survey of previous research on Livonian prosody". Linguistica Uralica 43, 1, 23-28.

Viitso, Tiit-Rein (2007) "Livonian gradation: types and genesis". Linguistica Uralica 43, 1, 45-62.

Viitso, Tiit-Rein (2007) “Album tulāb tāgiž kuodāj”. Līvõd jelāmi. The life of Livs, 5. Rīgõ: Līvõ Kultūr Sidām, Neputns.

Viitso, Tiit-Rein (2007) "The album returns home”. Lìvõd jelāmi. The life of Livs, 5-6. Rīgõ: Līvõ Kultūr Sidām, Neputns.

\section{8}

Viitso, Tiit-Rein (2008) Liivi keel ja läänemeresoome keelemaastikud. TartuTallinn: Eesti Keele Sihtasutus.

Viitso, Tiit-Rein (2008) "Liivi keele erijooned läänemeresoome keeleruumis". Liivi keel ja läänemeresoome keelemaastikud, 308-355. Tartu ja Tallinn: Eesti Keele Sihtasutus.

Lehiste, Ilse, Pire Teras, Valts Ernštreits, Pärtel Lippus, Karl Pajusalu, Tuuli Tuisk, and Tiit-Rein Viitso (2008) Livonian prosody. Helsinki: Suomalaisugrilainen Seura.

\section{9}

Viitso, Tiit-Rein (2009) "Livonian and Leivu: shared innovations and problems". Linguistica Uralica 45, 4, 269-282.

\section{0}

Viitso, Tiit-Rein (2010) "Salatsiliivi sõnaraamat”. Oma Keel 2, 104-107.

\section{1}

Viitso, Tiit-Rein (2011) “Liivi keele põhijooned”. In Renāte Blumberga, Tapio Mäkeläinen, and Karl Pajusalu, toim. Liivlased. Ajalugu, keel ja kultuur, 203-217. Tallinn: Eesti Keele Sihtasutus.

\section{2}

Viitso, Tiit-Rein and Valts Ernštreits (2012) Lìvõkīel-ēstikīel-lețkīel sõnārōntõz. Liivi-eesti-läti sõnaraamat. Lībiešu-igaunu-latviešu vārdnīca. Tartu and Rīga: Tartu Ülikool.

Viitso, Tiit-Rein (2012) "Concerning inflection classes in Livonian". Linguistica Uralica 48, 1, 12-26.

\section{3}

Vìtso, Tìts Reins (Viitso, Tiit-Rein) (2013) "Lībiešu valodas pamatiezīmes". In Renāte Blumberga, Tapio Mekeleinens, and Karls Pajusalu. Lībieši Vēsture, valoda un kultūra, 267-286. Rīga: Līvõ Kultūr sidām. 
34 Tuuli Tuisk, Karl Pajusalu

\section{4}

Viitso, Tiit-Rein (2014) "Constructions of obligation, duty, and necessity in Livonian”. Journal of Estonian and Finno-Ugric Linguistics 5, 1, 193-214.

\section{5}

Metslang, Helle, Karl Pajusalu, and Tiit-Rein Viitso (2015) "Negation in Livonian”. In Matti Miestamo, Anne Tamm, and Beáta Wagner-Nagy, eds. Negation in Uralic languages, 433-456. (Typological Studies in Language, 108.) Amsterdam: Benjamins.

\section{6}

Viitso, Tiit-Rein (2016) "The Essive in Livonian". Journal of Estonian and Finno-Ugric Linguistics 7, 1, 145-175.

Viitso, Tiit-Rein (2016) "Der finnische Dativgenetiv auf der Basis des wolgafinnischen Genitivs (Nobufumi Inaba: Suomen datiivigenetiivin juuret vertailevan menetelmän valossa)”. Finnisch-Ugrische Forschungen 63, 1-3. 